\title{
Proposal for a framework for production strategy utilizing Big Data: illustrative case in public service
}

\author{
Proposta de framework para Estratégia de Produção utilizando \\ Big Data: caso ilustrativo em serviço público
}

\author{
Fernando Celso de Campos $^{1}$ (i), Alceu Gomes Alves Filho ${ }^{2}$ (1) \\ ${ }^{1}$ Universidade Metodista de Piracicaba - UNIMEP, Programa de Pós-Graduação de Engenharia de Produção, \\ Santa Bárbara d'Oeste, SP, Brasil. E-mail: fernando.campos@unimep.br; \\ ${ }^{2}$ Universidade Federal de São Carlos - UFSCar, Departamento de Engenharia de Produção, São Carlos, SP, \\ Brasil. E-mail: alceu@ufscar.br
}

How to cite: Campos, F. C., \& Alves Filho, A. G. (2020). Proposal for a framework for production strategy utilizing Big Data: illustrative case in public service. Gestão \& Produção, 27(3), e4651. https://doi.org/10.1590/0104-530X4651-20

\begin{abstract}
The production strategy is an overall pattern of decisions and actions that defines the role, objectives and production activities supporting a business strategy. Expanded to a general pattern of decisions determining the long-term skills and their contributions to the global strategy combining market requirements and resources. Currently, from the whole evolution of the internet and its related technologies, there are a wide range of data available in various formats and storage places. This voluminous data set available, called Big Data, can support the understandings and managerial and strategic visions in a way interesting, effective and relevant, since they combine some factors and tools. Therefore, the objective of this article is to present a proposal for a framework that supports the strategy of production via use of aspects of Big Data. The method of research was conducted in three stages: i) literature search in 5 steps; ii) elaboration of a theoretical-conceptual framework (BD-ProdStrateg) in 5 steps; and iii) application of illustration of the proposed framework (BD-ProdStrateg). The main contribution was the systematization of a proposal using a theoretical right to authors of consolidated production strategy and on the other hand the latest reference about Big Data and its possibilities to be explored. Illustrative application generated an expectation of continuity and search for technological means to check on how long the main problems would be resolved and what degree of economics from this deployment.
\end{abstract}

Keywords: Production strategy; Big Data; Framework; Public service; Illustrative case.

Resumo: A estratégia de produção é um padrão global de decisões e ações que define o papel, os objetivos e as atividades da produção apoiando uma estratégia de negócios. Ampliou-se para um padrão geral de decisões que determina as competências a longo prazo e suas contribuições para a estratégia global conciliando requisitos de mercado e recursos de operações. $\mathrm{Na}$ atualidade, a partir de toda evolução da internet e de suas tecnologias afins, há uma grande gama de dados disponibilizados nos mais diversos formatos e lugares de armazenamento. Esse volumoso conjunto de dados disponíveis, chamado de Big Data, pode dar suporte à compreensões e visões gerenciais e estratégicas de um modo interessante, eficaz e relevante,

Received Feb. 16, 2018 - Accepted July 11, 2018

Financial support: None.

This is an Open Access article distributed under the terms of the Creative Commons Attribution License, which permits unrestricted use, distribution, and reproduction in any medium, provided the original work is properly cited. 
desde que se combinem alguns fatores e ferramentas. Portanto, o objetivo desse artigo é apresentar uma proposta de framework que suporte a estratégia de produção via utilização de aspectos de Big Data. O método de pesquisa foi realizado em três etapas: i) pesquisa bibliográfica em 5 passos; ii) elaboração de um framework teórico-conceitual (BD-ProdStrateg) em 5 passos; e iii) aplicação de ilustração do framework proposto (BD-ProdStrateg). A contribuição principal foi a sistematização de uma proposta utilizando-se um referencial teórico bem consolidado de autores de estratégia de produção e por outro lado o referencial mais recente acerca de Big Data e de suas possibilidades a serem exploradas. A aplicação ilustrativa gerou uma expectativa de continuidade e de busca por meios tecnológicos para se verificar em quanto tempo os principais problemas seriam solucionados e qual o grau de economia advindo dessa implantação.

Palavras-chave: Estratégia de produção; Big Data; Framework; Serviço público; Caso ilustrativo.

\section{Introduction}

For Slack et al. (1995), the production strategy is the overall pattern of decisions and actions that defines the role, objectives and production activities supporting the business strategy of the organization. That definition was expanded in Slack \& Lewis (2002) as a general pattern of decisions determining the long-term skills and their contributions to the global strategy of any kind of operation, through the reconciliation of market requirements with the operations resources. Namely that conciliation is, in practice, process or how the operation strategy is formulated. Already the content means the set of decisions that are made (either intentionally or automatically) within the domain of the operations strategy, aiming at synergy and harmonization between the understanding of markets (outside view) and understanding the resources and processes (inside view). This lists the required performance via the performance objectives and the strategic decisions that format and develop the direction of long-term operation, in relation to the allocation of resources, for what is called decision areas.

The understanding of markets or outside view can be supported by the use of which has been conventionally called Big Data,

[...] a generic term for data that cannot be contained in the usual repositories; refers to data too bulky to fit on a single server; not too structured to suit a database organized into rows and columns; or too fluid to be stored in a data warehouse, in the view of static (Davenport, 2014, p.14).

Also, it is interesting to note that, from the proposal of the fourth industrial revolution or Industry 4.0, aimed at vertical and horizontal integration of value chains, enabling technologies such as the Internet of things (IoT), Cyber-Physical Systems (CPS), in addition to the Big Data, because that will influence impacts arise technologies available to aid in decision making, strategic positioning and competitiveness in the global market (Kagermann et al., 2013; Haddara \& Elragal, 2015). Lee et al. (2014) consider the Big Data as the core of the aggregation of data and the key to the sustainability of innovation in this new environment. Theorin et al. (2016) proposed a prototype-oriented information model (Line Information System Architecture - LISA) because of the importance and need to refine the information in large volume, velocity and variety (characteristics of the Big Data) to direct, to integrate devices and services, turning it into high level knowledge for decision support. Wang et al. (2016) proposed a framework for intelligent factory where the Big Data served as Assistant for 
organization and coordination of the information generated and consumed between the industrial network and physical resources. Load Balancing in a smart factory used the Big Data as control enabler of information ensuring an efficient operational strategy (Lii et al., 2017). Santos et al. (2017) describe that in this new context (3V and Industry 4.0), the Big Data generates opportunities to improve the sustainable innovation and operations as proof that presented an analytical architecture applied in a Bosch unit in Portugal. Therefore, there is a possibility to join the production strategy with aspects of Big Data because the dynamism of markets around to achieve competitive advantage is something present and current management context.

Having said that, there is the problem of search: "How can structured support the production strategy using aspects of the data processing of Big Data."

Therefore, the objective of this article is to present a proposal for a framework that supports the strategy of production via use of aspects of Big Data.

The next section presents the theoretical foundation of the main elements to be used in the composition of the framework involving production strategy and Big Data, following the method adopted and some bibliographical findings, the proposal is discussed briefly by way of a preliminary conceptual presentation and the final considerations are made.

\section{Production strategy: definition and main features}

It is important to consider the hierarchy of three levels as strategies presented by Hayes \& Whellwright (1984), Mills et al. (1995), Hayes et al. (2004), Johnson et al. (2009): corporate strategy (Group of companies), the competitive strategy or business (Enterprise or business unit of the Group) and the functional strategy (function or sector of a company: production, marketing, technology, finance, among others). Competitive strategy, Porter (1980) proposed that, to meet the five competitive forces of an industrial segment (bargaining power of customers, bargaining power of suppliers, competitors, threat of substitute products, threat of new entrants), a company may use a generic competitive strategy as the types: cost leadership, differentiation and focus. Hörte et al. (1987) reinforce that decisions of competitive strategy should be based on careful analysis of the environment and of forces/company's own weaknesses. The market requirements perspective on the production strategy has your required performance evaluation by performance objectives, proposed by several authors. Meyer et al. (1989), Hill (1995), Slack et al. (1995), Slack \& Lewis (2002), point the following performance objectives: quality, delivery (speed and reliability), flexibility and cost. To summarise, the production strategy in the hierarchy of the strategies supports the implementation of the business strategy that has the market vision, you can define a generic competitive strategy and that has the performance objectives to evaluate your performance.

In addition, Hill (1995) proposes 5 steps for the formulation of production strategy considering some other aspects, such as: i) Step 1: definition of corporate objectives (strategic vision macro); ii) Step 2: defining the marketing strategy (vision); iii) Step 3: definition of the criteria qualifiers (above the basic level of performance in the industry) and winners (key reasons to buy). Qualifiers are criteria of assessment to which the products are considered possible candidates for purchase. Winning criteria identify the differentiation between the products or services of two companies; iv) Step 4: choice of process to produce and deliver products; v) Step 5: definition of the necessary infrastructure. 


\section{Big Data: definition, concepts and basic structuring elements of a framework}

Davenport et al. (2012) claim that the term Big Data is used so distorted by solution providers to classify data analysis systems, when in reality it is more than that, allowing the emergence of new possibilities and services, encouraging companies to respond to new demands in a more agile and more assertive, competing more effectively in the market. The main goal of the Big Data analysis is to help companies take better business decisions. Data scientists and other users analyze large amounts of data transactions, as well as other data sources that can be ignored by traditional business intelligence software, such as web server logs, media activity reports social, mobile phone records and data obtained by means of sensors. The analysis of data can allow a targeted marketing approach that gives the company a better understanding of their customers. An understanding that will influence the internal processes and, ultimately, increase profit, which provides the competitive advantage that most companies are seeking (ISACA, 2016). The rationale for the study and application of the Big Data is search meet the growing pursuit of efficiency and effectiveness in the use of it tools, to obtain significant reward and differentiate itself from competitors. It is important that leaders of organizations, mostly IT professionals, concentrate on the information demand Big Data.

According to IBM (2016), the Big Data can be characterized by "5V": Volume; Velocity; Variety; Veracity; Value. Volume refers to the greater amount of data being generated from a variety of sources, and for Novo (2014) there is no precise definition of this measure, and to Olofson et al. (2011) this issue of the volume depends on the case and the nature of the data. Wamba et al. (2015) reported several works about these characteristics as well as exemplify each one of them, which was also more detailed in Akter \& Wamba (2016). Velocity of information processing, which allows near-instant analysis of the data, enabling the company to be more nimble, bringing quick perspectives, which can allow a supermarket chain, for example, create offers real-time marketing to their consumers (McAfee \& Brynjolfsson, 2012). According to Davenport et al. (2012) makes it necessary for companies to think about and consider the continuous flow of information and processes, analyzing the data as these are generated, rather than just storing them in large databases for later analysis. Variety as Novo (2014) points refers to various sources of data: messages, reading sensors, security cameras, GPS devices; mobile phones, RFID, among others, that can be used for analysis and subsequent extraction of relevant information to the business. The sources for the Big Data can include everything from call centers voice data, obtained by genome data to biological research and medical, and can also come from the most diverse origins, as a copier or even a Jet engine (Davenport et al., 2012; Brown et al., 2011). Veracity has to do with the quality of data and information, and are essential features for interested users (executives, policymakers and society in General) use and reuse these real and appropriate data, generating useful information and true to themselves. Verification of data collected for suitability and relevance to the purpose of the analysis is a key point to get data that add value to the process (Halper \& Krishnan, 2013). Immediate value of most data is evident for those who collect, on finding Mayer-Schönberger \& Cukier (2013b). They discuss such feature of Big Data, saying that the value of the data, the matter of primary use for potential use in the future, creating a profound effect: affects how business value your information and to whom give access to them (Mayer-Schönberger \& Cukier, 2013a). This allows, and 
perhaps even force, companies to change their business models and changes the way they see and use the data.

Sheng et al. (2017) performed a review on the multidisciplinary perspective of Big Data and came to some comparative tables on business management. Among the many claims made by they highlight both the availability of information in various sources as your feasibility of obtaining are critical conditions for a good strategic decision making process. In addition, these same authors have proposed a framework in 3 stages of Big Data value crossed with management practices in terms of: organizational change, strategic decision making and business development. In the same way, Sivarajah et al. (2017) highlight some challenges about the data analysis of Big Data and analytical methods in force, supplemented by Kambatla et al. (2014) that point analyses trends in Big Data. Siddiqa et al. (2016) highlight management techniques for Big Data and draw attention not only to the storage, processing, preprocessing and also for the security of data and subsequent analysis. For Agrawal et al. (2011) there's a Big Data analysis pipeline consisting of 5 phases in flux: i) Phase 1: acquisition and recording of data; ii) Phase 2: extraction - cleaning notes on the data; iii) Phase 3: integration-Aggregation-data Representation; iv) Phase 4: analysis and modeling; v) step 5: interpretation. However, these authors highlight that in each of these stages there are needs that make these challenging tasks. Davenport (2014) submitted 3 dimensions to consider on deployment and utilization strategy of Big Data: i) Dimension 1: "focus on a problem!" with double meaning: meaning a-internal environment for the Big date ("new internal situation-innovation or amendment which attract interest? ") and two - the Big date for the internal environment ("new situation or external innovation-external news should have knowledge?"; ii) Dimension 2: array of goals and implementation stages. Objectives of value from the Big Data: download costs, faster decisions (time), better decisions (focus-objectivity), innovation of product or service. Stages of implementation: findings (what? Who?) and production (what? Who?); iii) Dimension 3: fast \& Aggressiveness against the competition to adopt the Big Data (proposes analyzing 3 situations: Conservative? Moderately aggressive? Too aggressive?).

\section{Research method}

The research method was built from the description of Turrioni \& Mello (2012) that classify the scientific researches in the field of production engineering for the classic, analyzing the variables: nature, objectives, approach and method. For this classification, this research is applied in nature since it sought answers to using the Big Data in supporting production strategy described in the literature, these responses aimed at practical applications through frameworks. This research is exploratory because it aimed to provide greater familiarity with the problem to make it explicit, bibliographical and documental junction involved in practical situation related to the problem researched, as well as analysis of examples to facilitate understanding. And that by revealing the importance of intrinsic aspects to the processes and phenomena of the studied environment and don't always get quantifiable data for the use of statistical tools, her approach is considered qualitative.

Therefore, three methodological stages: i) literature search in 5 steps; ii) elaboration of a theoretical-conceptual framework (BD-ProdStrateg) in 5 steps; and iii) application of illustration of the proposed framework (BD-ProdStrateg). 


\subsection{Stage 1: bibliographical research}

As has been mentioned above the bibliographical research was performed in 5 steps, described and detailed below:

- step 1: defining search strings in the CAPES Journal Portal;

- step 2: identify the 7 major databases that had more papers in this thematic publications;

- step 3: identification of 12 major journals had papers publications more in this theme;

- step 4: identification of 9 top authors who have published in this theme;

- step 5: review and selection of the 6 main papers authors more found at the intersection of search strings.

In step 1, set the search strings and search strategy in these strings (if the keywords would be in any one of the elements: title, abstract and key words, or just in the title), the amount of articles found were recorded in Table 1. We used three search filters: i) period of 10 years: 2007 to 2017; ii) publication type: papers in periodicals; iii) only peer-reviewed papers.

Table 1. overview of the CAPES Portal search.

\begin{tabular}{llll}
\hline \multicolumn{1}{c}{ Search String I } & \multicolumn{1}{c}{ Search String II } & \multicolumn{1}{c}{ Search String III } & Search String IV \\
\hline $\begin{array}{l}\text { Big Data AND } \\
\text { framework }\end{array}$ & $\begin{array}{l}\text { Big Data AND } \\
\text { operations strategy }\end{array}$ & $\begin{array}{l}\text { Big Data AND } \\
\text { manufacturing } \\
\text { strategy }\end{array}$ & $\begin{array}{l}\text { Big Data AND } \\
\text { strategy }\end{array}$ \\
\hline $\begin{array}{l}\text { Big Data (title), } \\
\text { framework (any part) }\end{array}$ & $\begin{array}{l}\text { Big Data (title), } \\
\text { operations } \\
\text { strategy(any part) }\end{array}$ & $\begin{array}{l}\text { Big Data (title), } \\
\text { manufacturing } \\
\text { strategy(any part) }\end{array}$ & $\begin{array}{l}\text { Big Data (title), } \\
\text { strategy(any part) }\end{array}$ \\
\hline 714 papers & 235 papers & 79 papers & 464 papers \\
\hline
\end{tabular}

Source: prepared by the authors.

In step 2, crossed the information gathered between the search strings and data Bases, coming up to 7 main of them with greater number of publications of articles in this theme. In Figure 1, the table is organized in descending order of the number of articles found in the databases for each of the search strings, i.e. in the Search String 1 (see Table 1) met 468 articles in SCOPUS, 372 in OneFile (GALE), and so on. 


\section{Databases-Top' 7}

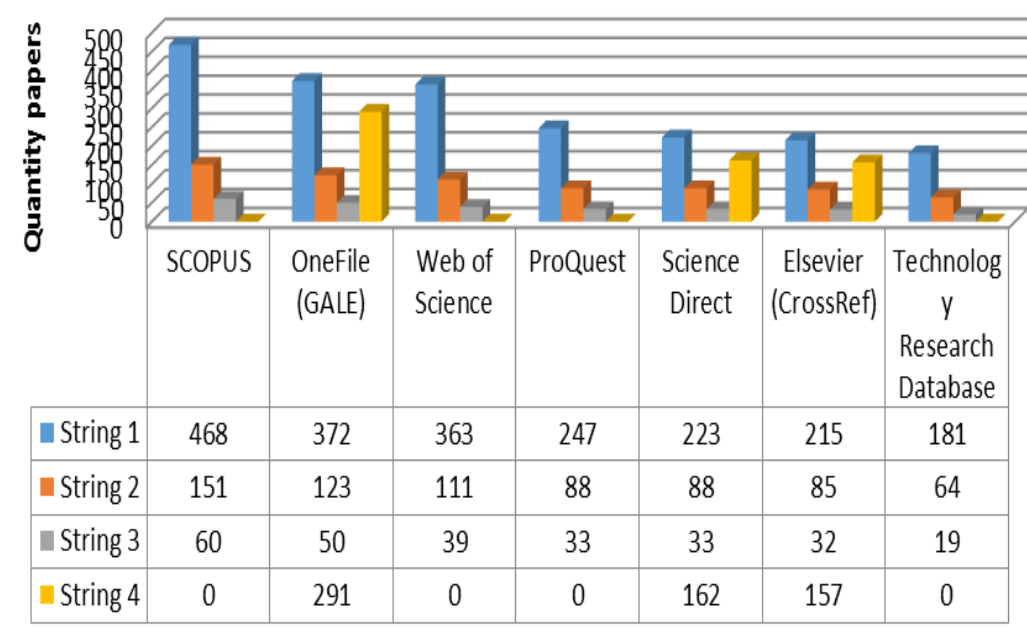

Figure 1. Top 7 - databases with largest number of publications. Source: prepared by the authors based on research results.

Step 3 has identified the publications of articles in research in a clipping of the 12 leading periodicals. Figure 2 presents the amount of publications collected by the application of search strings, in decreasing order of incidence in periodicals. Below these 12 journals that were identified were journals with occurrences in a string of search in isolation, therefore, were excluded from the analysis.

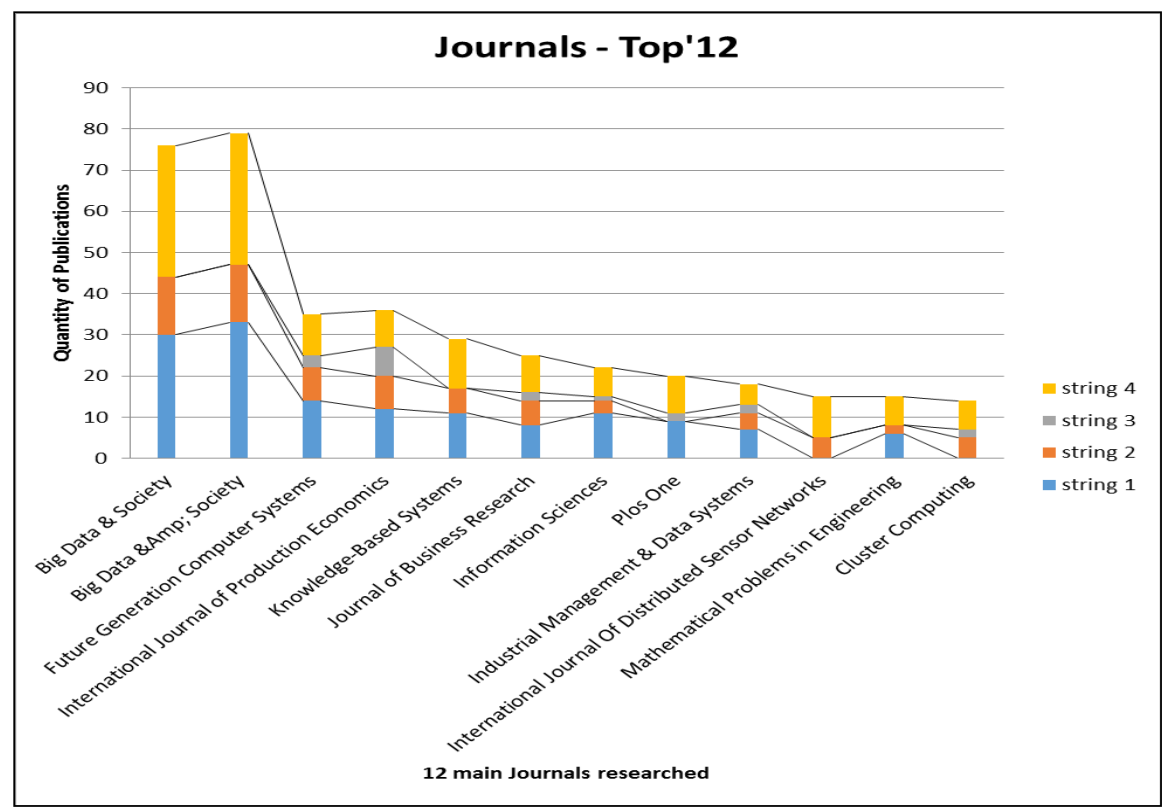

Figure 2. Top 12 - Journals with the highest number of publications versus search strings. Source: prepared by the authors based on research results. 
In step 4, was made a cutout of the nine main authors who published in this theme. Highlight that the criterion for this cut was to have publications found in at least two of the search strings.

If the authors were only in two strings privileged-if the search string II and search string IV due to clipping, outside these fetched theme clipping strategies the authors have not been considered for analysis.

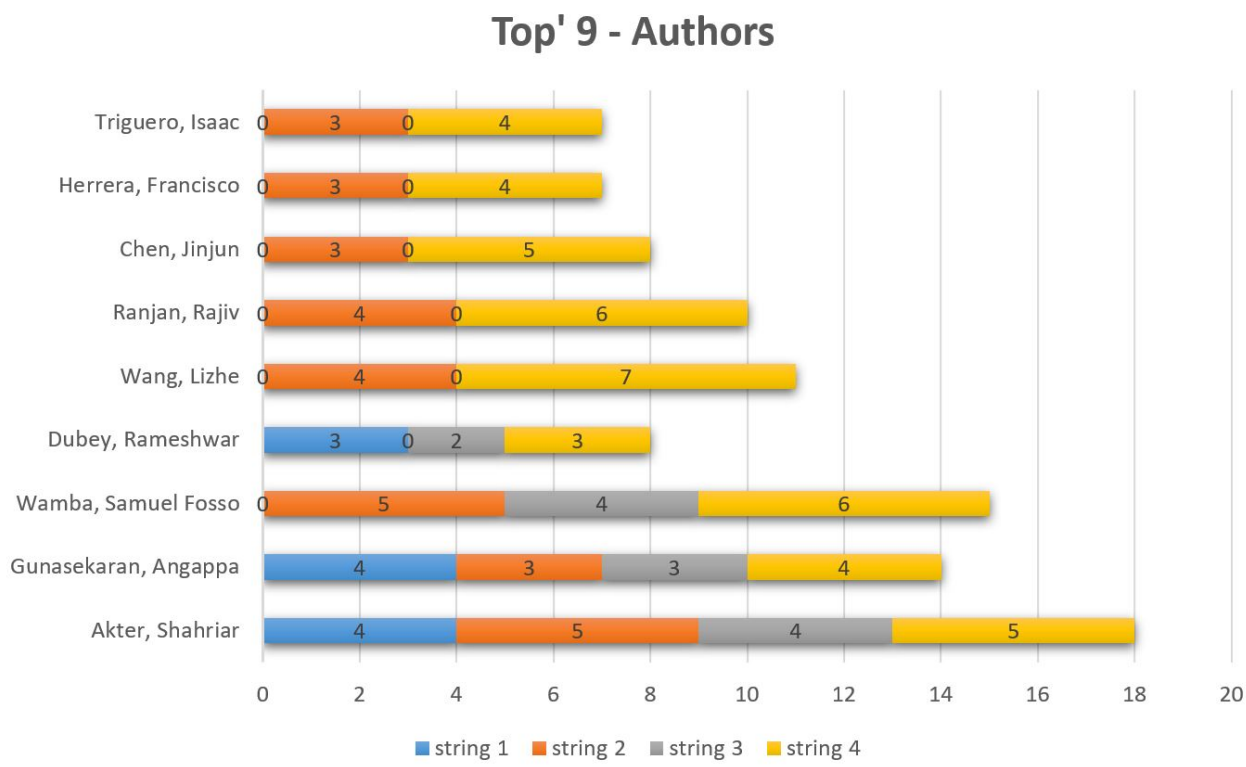

Figure 3. Top 9 - Authors with the highest number of publications versus search strings. Source: prepared by the authors based on search results.

Figure 3 presents the number of publications for each search string, in ascending order of occurrences, a generic form without excluding the possible repetitions occurring. On all four strings at the same time are the authors: Akter (18 occurrences) and Gunasekaran (14 cases). In 2, 3 and 4 strings is the author Wamba (15 cases). The strings 1,3 and 4 are Dubey ( 8 instances). In just the two strings 2 and 4 are: Wang (11 cases), Ranjan (10 instances), Chen (8 instances), Herrera (7 instances) and Triguero (7 instances).

In step 5, the reading and analysis of the items raised in step 4, with an additional clipping of the first six authors (Akter, Gunasekaran, Wamba, Dubey, Wang and Ranjan) found at the intersection of search strings, occurring in 4 or 3 of them. It was considered the abstract, introduction and conclusion of each article. After this procedure there was a decision of selection (or not) the article and flipped to register some information to your respect. The Table 2 presents a summary of the record of some selected works of these first 6 authors chosen, it is organized by ascending order of publications. 
Table 2. overview of selected articles of the authors found in the search.

\begin{tabular}{|c|c|c|c|}
\hline Author (year) & Article title & $\begin{array}{c}\text { Purpose of the } \\
\text { Article }\end{array}$ & Relevant Aspects \\
\hline $\begin{array}{l}\text { Wamba et al. } \\
\text { (2015) }\end{array}$ & $\begin{array}{l}\text { How 'Big Data' can } \\
\text { make big impact: } \\
\text { findings from a } \\
\text { systematic review } \\
\text { and a longitudinal } \\
\text { case study }\end{array}$ & $\begin{array}{l}\text { Present an interpretive } \\
\text { framework that } \\
\text { analyzes the prospects } \\
\text { for the definition and } \\
\text { applications of Big } \\
\text { Data }\end{array}$ & $\begin{array}{l}\text {-systematic review- } \\
\text { longitudinal case study } \\
\text {-Big Data can } \\
\text { develop superior } \\
\text { capabilities that } \\
\text { become a decisive } \\
\text { competitive } \\
\text { advantage } \\
\text {-eco-information } \\
\text { system to share } \\
\text { information and } \\
\text { develop insights for } \\
\text { decision making. }\end{array}$ \\
\hline Dubey et al. (2015) & $\begin{array}{l}\text { The impact of Big } \\
\text { Data on world- } \\
\text { class sustainable } \\
\text { manufacturing }\end{array}$ & $\begin{array}{l}\text { Illustrate the role of Big } \\
\text { Data Analysis in } \\
\text { supporting sustainable } \\
\text { manufacture of world } \\
\text { class }\end{array}$ & $\begin{array}{l}\text { World-Class } \\
\text { Sustainable } \\
\text { Manufacturing } \\
\text { (WCSM)-framework } \\
\text { and its indicators } \\
\text {-framework from the } \\
\text { literature reviewed } \\
\text {-psychometric } \\
\text { properties of the } \\
\text { instrument } \\
\text { developed } \\
\text { measuring items. }\end{array}$ \\
\hline $\begin{array}{l}\text { Akter \& Wamba } \\
(2016)\end{array}$ & $\begin{array}{l}\text { Big Data Analytics } \\
\text { in e-commerce: a } \\
\text { systematic review } \\
\text { and agenda for } \\
\text { future research }\end{array}$ & $\begin{array}{l}\text { Explore and take a } \\
\text { position on the use of } \\
\text { Big Data in e- } \\
\text { commerce based on a } \\
\text { systematic review of } \\
\text { the literature }\end{array}$ & $\begin{array}{l}\text {-commercial value } \\
\text { and challenges of } \\
\text { BDA in electronic } \\
\text { commerce } \\
\text {-wide discussions } \\
\text { about future } \\
\text { challenges and } \\
\text { research } \\
\text { opportunities } \\
\text {-synthesize various } \\
\text { concepts of BDA } \\
\text {-transversal analysis } \\
\text { applications in } \\
\text { electronic commerce }\end{array}$ \\
\hline Wang et al. (2016) & $\begin{array}{l}\text { Big Data analytics } \\
\text { in logistics and } \\
\text { supply chain } \\
\text { management: } \\
\text { certain } \\
\text { investigations for } \\
\text { research and } \\
\text { applications }\end{array}$ & $\begin{array}{l}\text { Review and rate the } \\
\text { literature of application } \\
\text { of Big Data analytics } \\
\text { business in logistics } \\
\text { and supply chain } \\
\text { management. }\end{array}$ & $\begin{array}{l}\text {-framework of Supply } \\
\text { Chain Analytics } \\
\text { maturity (SCA). } \\
\text {-framework is on five } \\
\text { levels of capability } \\
\text { under two broad } \\
\text { categories (strategic } \\
\text { and operational) } \\
\text {-strategic Logistics } \\
\text { and Supply Chain } \\
\text { Management (LSCM) } \\
\text { encompasses levels: } \\
\text { sustainability, agile } \\
\text { and collaborative. } \\
\text {-Operating LSCM } \\
\text { encompasses levels: } \\
\text { based on processes } \\
\text { and functional. }\end{array}$ \\
\hline
\end{tabular}


Table 2. Continued...

\begin{tabular}{|c|c|c|c|}
\hline Author (year) & Article title & $\begin{array}{c}\text { Purpose of the } \\
\text { Article }\end{array}$ & Relevant Aspects \\
\hline Akter et al. (2016) & $\begin{array}{l}\text { How to improve } \\
\text { firm performance } \\
\text { using Big Data } \\
\text { analytics capability } \\
\text { and business } \\
\text { strategy } \\
\text { alignment? }\end{array}$ & $\begin{array}{l}\text { Proposal for a model } \\
\text { BDAC (Big Data } \\
\text { analytics capability) } \\
\text { designed with the } \\
\text { theory of vision based } \\
\text { on resources (RBT) } \\
\text { and tangled vision of } \\
\text { sociomaterialismo }\end{array}$ & $\begin{array}{l}\text {-Big Date } \\
\text { compensates for } \\
\text { some companies but } \\
\text { it seems that few } \\
\text { have achieved } \\
\text { something significant } \\
\text { and impact. } \\
\text { - } 2 \text { based Delphi } \\
\text { studies research and } \\
\text { online surveys } \\
\text { involving } \\
152 \text { business } \\
\text { analysts Americans. } \\
\text { hierarchical } \\
\text { structural model } \\
\text { BDAC with } 3 \text { primary } \\
\text { dimensions of } \\
\text { capacity } \\
\text { (management, } \\
\text { technology, talent) } \\
\text { and } 11 \text { sub- } \\
\text { dimensions } \\
\text { concerning the } \\
\text { management, } \\
\text { technology, talent. }\end{array}$ \\
\hline Vögler et al. (2016) & $\begin{array}{l}\text { Migrating Smart } \\
\text { City } \\
\text { Applications to the } \\
\text { Cloud }\end{array}$ & $\begin{array}{l}\text { Present the intelligent } \\
\text { city operating system } \\
\text { (SCOS), a central } \\
\text { element of the future } \\
\text { application ecosystem } \\
\text { intelligent city. The } \\
\text { SCOS is designed to } \\
\text { resemble a modern } \\
\text { computer operating } \\
\text { system, provides } \\
\text { underlying resources } \\
\text { and unified } \\
\text { management tasks of } \\
\text { abstractions, but } \\
\text { specifically adapted to } \\
\text { the scale of the city. }\end{array}$ & $\begin{array}{l}\text {-specific } \\
\text { fundamentals of } \\
\text { SCOS that allow } \\
\text { greater application } \\
\text { ecosystem intelligent } \\
\text { city, allowing } \\
\text { stakeholders and } \\
\text { citizens to create } \\
\text { applications } \\
\text {-this approach allows } \\
\text { you to build } \\
\text { applications focusing } \\
\text { on just your specific } \\
\text { demand, freeing } \\
\text { them full of } \\
\text { complexities and } \\
\text { problems we are } \\
\text { facing today. }\end{array}$ \\
\hline $\begin{array}{l}\text { Wamba et al. } \\
(2017)\end{array}$ & $\begin{array}{l}\text { Big Data analytics } \\
\text { and firm } \\
\text { performance: } \\
\text { effects of dynamic } \\
\text { capabilities }\end{array}$ & $\begin{array}{l}\text { Proposed extension of } \\
\text { the Big Data analytics } \\
\text { capability (BDAC) } \\
\text { model by analyzing } \\
\text { both the performance } \\
\text { of businesses } \\
\text { (financial and market) } \\
\text { as the process- } \\
\text { oriented dynamic } \\
\text { capabilities (PODC). }\end{array}$ & $\begin{array}{l}\text {-297 based online } \\
\text { surveys research } \\
\text { involving business } \\
\text { analysts and } \\
\text { managers with } \\
\text { experience in Big } \\
\text { Chinese Date. } \\
\text {-findings confirmed } \\
\text { the value of the } \\
\text { concept of } \\
\text { hierarchical model } \\
\text { BDAC entanglement } \\
\text { with direct and } \\
\text { indirect impact on } \\
\text { company } \\
\text { performance (or Firm }\end{array}$ \\
\hline
\end{tabular}


Table 2. Continued...

\begin{tabular}{|c|c|c|c|}
\hline Author (year) & Article title & $\begin{array}{c}\text { Purpose of the } \\
\text { Article }\end{array}$ & Relevant Aspects \\
\hline & & & $\begin{array}{l}\text { Performance - } \\
\text { FPER). } \\
\text {-the end discuss } \\
\text { some implications for } \\
\text { practice and } \\
\text { research. }\end{array}$ \\
\hline
\end{tabular}

Source: prepared by the authors based on search results.

\subsection{Stage 2: elaboration of a theoretical-conceptual framework (BD- ProdStrateg)}

The development of the theoretical-conceptual framework BD-ProdStrateg was held in 5 steps described in General as a result and that will be detailed in the results and discussion section.

- Step 1 - Understanding the framework of operations strategy proposed by Slack et al. (2015), Slack \& Lewis (2002), supplemented by Chase et al. (2003);

- Step 2 - Research about frameworks that operacionalizam Big Data in General;

- Step 3 - Looking for opportunities to use the Big date in the framework of the Step 1;

- Step 4 - Preparation of hybrid from the research framework and opportunities found;

- Step 5 - Presentation of the theoretical-conceptual framework for use and support the production strategy, entitled BD-ProdStrateg.

\subsection{Stage 3: application of illustration of the proposed framework (BD-ProdStrateg)}

The title of a proposed framework illustration application and due to the convenience of having the necessary information, diverse and with easy access, was selected the Municipal water and sewage treatment (SAAE-SC) serving a city with population around 250,000 inhabitants. The SAAE-SC was created to provide water supply services, removal and treatment of sewage, among others, seeking a sustainable urban environment. The SAAE-SC has a number of demands and service channels, as shown in Figure 4 illustrates the general structure composed of your Presidency and decision-making and strategic body maximum and at the level below the two bureaus: Administration (SuAd) and Projects and Operations (SuPo). The SuPo has 4 areas: Maintenance and Operations (GMO), Works and Sanitation (GOS), Water and Sewage Treatment (GOTAE) and Planning and Projects (GPP). The GOS has 3 sections: Works (SO), Maintenance of Networks (SMR), Control of Losses (SCP).

Therefore, identified the opportunity to apply the framework BD-ProdStrateg due to various sources of information to be analyzed and the various problems related to the services provided, aiming at improving projections from the indication of priorities and focuses of action operational.

At present, there is a monthly demand average around 350 calls (domestic driveways and public roads) that are served in the short, medium and long term, an average of 10 to 15 new leaks per day.

The larger leaks in primary networks and smaller, secondary networks. 


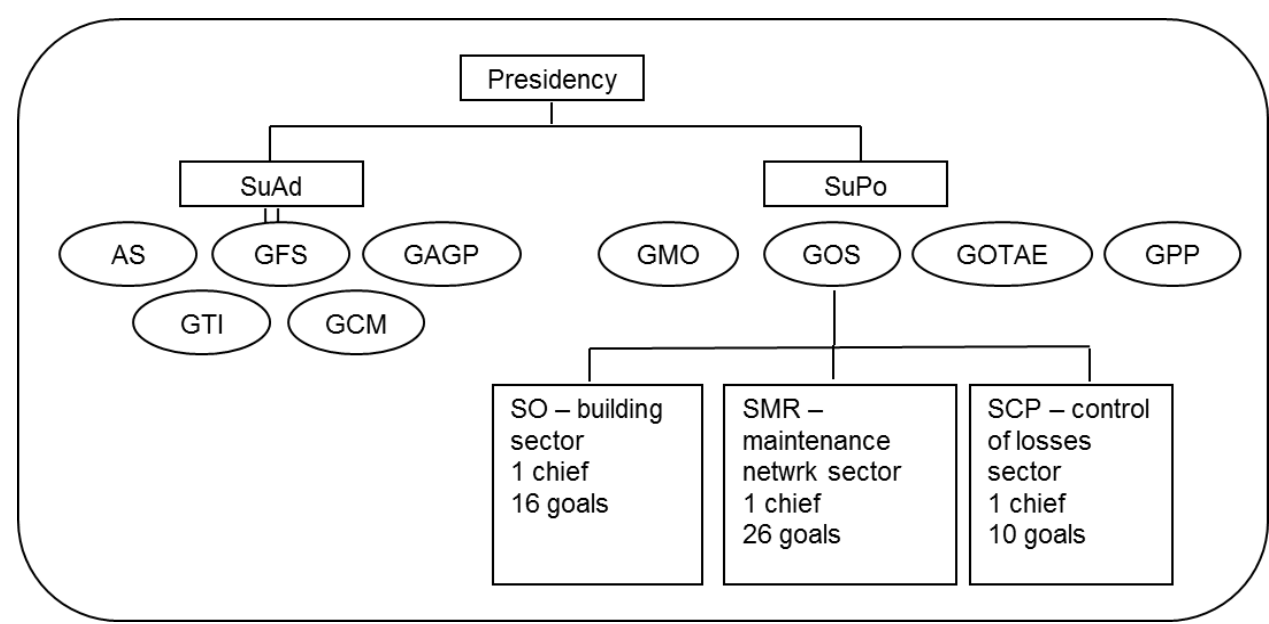

Figure 4. Overall structure of SAAE-SC. Source: prepared by the authors from the institutional website of SAAE-SC.

In February 2017, a new President took over the SAAE-SC and put a service goal at least 20 leaks/day and solving the problems in final, the prospect was that throughout the year of 2017 could zero out this kind of problem in the city. In addition, there are a considerable number of complaints on the part of users of the services of the SAAE-SC: i) problem in the markup of the hydrometer; ii) recovery of wrong account; iii) amount used of water registered wrong; IV) installation request/exchange of hydrometer; and other reasons that fall under exceptions and has a direction made by the staff. For various reasons beyond the apparent leaks there is a perspective that around $45 \%$ of treated water is lost by the primary and secondary network, mostly through leaks hidden around the city that can take a long time before being detected, because, the pipe is very old, with more than 30 years.

\section{Results and discussion}

Below are detailed the results from Stage 2 that made the development of the theoretical-conceptual framework proposed hybrid through 5 steps described in the previous section.

\subsection{Step 1 - Understanding the operations strategy frameworks proposed in Slack et al. (2015), Slack \& Lewis (2002), supplemented by Chase et al. (2003)}

It appears four large blocks, analyzed by these authors, to be considered in the strategy of operations (or production), they are: i) market requirements (performance required to Act); ii) resources of operations (strategic decisions, skills and processes); iii) interpretation of higher-level strategy (business and Enterprise); iv) operational experience (emerging sense that the strategy should be). 


\subsection{Step 2 - Research about frameworks that operacionalizam Big Data in General}

Some frameworks were found, namely: Liu (2015) propose an analytical CRM via Big Data, Campos (2015) propose a framework for managing innovation in knowledgeintensive services, Seo et al. (2016) propose a framework of Big Data for patents, whose goal is to support the strategic planning of $P \& D$, the authors Jelinek \& Bergey (2013), propose a Big Data Analytics framework linking a theoretical model of market orientation and resource-based View (RBV) coupled with Knowledge-based Vision (KBV).

\subsection{Step 3 - Looking for opportunities to use the Big date in the framework of the Step 1}

Analyzing the four large blocks mentioned by the authors of the Step 1 on aspects of production strategy, as well as research about Big Data of Step 2, identified some opportunities to RAID the Big Data in decision-making of planning and operations related to the operations strategy (or production) so generic but can be applied to the SAAE-SC. aspects and opportunities are presented in Table 3.

Table 3. Big Data incursion opportunities in production strategy.

\begin{tabular}{|c|c|}
\hline Aspects of Production Strategy & $\begin{array}{l}\text { Incursion of Big Data } \\
\text { opportunities }\end{array}$ \\
\hline Market requirements & $\begin{array}{l}\text {-Analyses to evaluate performance of } \\
\text { products and services; } \\
\text {-Analytical CRM - Customer Relationship } \\
\text { Management for identifying new needs of } \\
\text { customers already-active marketing; } \\
\text {-Analyses of new potential customers - } \\
\text { marketing involved; } \\
\text {-Analyses of competition in relation to } \\
\text { existing products and services or new } \\
\text { releases. }\end{array}$ \\
\hline Operations resources & $\begin{array}{l}\text { Information about procurement and approval } \\
\text { of new suppliers }\end{array}$ \\
\hline Interpretation of the higher level strategy & $\begin{array}{l}\text {-analyses relative: when it was done and it } \\
\text { worked, to new trends, innovations, the } \\
\text { guidelines for new projects and new } \\
\text { strategies. }\end{array}$ \\
\hline Operating experience & $\begin{array}{l}\text { - dynamics of lessons learned with all the } \\
\text { information captured and knowledge } \\
\text { acquired from Big Data analysis. }\end{array}$ \\
\hline
\end{tabular}

Source: prepared by the authors.

\subsection{Step 4 - Preparation of hybrid from the research framework and opportunities found}

From the survey and the reflections undertaken with the experiences reported by other frameworks proposed in the literature a trend was proved: we must get the simplicity, the regularity of analysis, amidst the chaos and diversity of Big Data data sources. Also, another finding, is that there is a technological impediment due to 
various possibilities depending on what is needed exclusively analyze or search in Big Data. Soon, there is a great importance of data analysis Model (or Data Model), which is the center of the whole decision-making process stemming from it, that is, if this template is inappropriate then the result will be inadequate and inappropriate for a safe decision.

From the adaptation of 5 Stages proposed by Agrawal et al. (2011) a general framework scheme of Big Data, shown in Table 4.

Table 4. Overview of composite layers of a framework of Big Data.

\begin{tabular}{|c|c|c|c|c|}
\hline Phase I & Phase II & Phase III & Phase IV & Phase V \\
\hline $\begin{array}{l}\text { Purchase and } \\
\text { registration }\end{array}$ & $\begin{array}{l}\text { Extraction, } \\
\text { cleanup and } \\
\text { notes }\end{array}$ & $\begin{array}{l}\text { Integration, } \\
\text { aggregation and } \\
\text { representation }\end{array}$ & $\begin{array}{l}\text { Analysis and } \\
\text { modeling }\end{array}$ & Interpretation \\
\hline $\begin{array}{c}\text { Heterogeneity } \\
\text { and Incomplete } \\
\text { data }\end{array}$ & Tick data & $\begin{array}{c}\text { Timeliness of } \\
\text { data }\end{array}$ & $\begin{array}{l}\text { Data privacy } \\
\text { and origin of } \\
\text { Sources }\end{array}$ & $\begin{array}{c}\text { Human } \\
\text { collaboration for } \\
\text { analysis and } \\
\text { interpretation of } \\
\text { data }\end{array}$ \\
\hline $\begin{array}{c}\text { Data Source } \\
\text { Layer }\end{array}$ & ETL Layer & $\begin{array}{c}\text { Data Storage } \\
\text { Layer }\end{array}$ & Analysis layer & User layer \\
\hline
\end{tabular}

Source: prepared by the authors. ETL = Extract-Transform-Load.

It is the Phase I which acquires and register the information collected generally in Big Data, for Phase II extracting, cleaning and noting highlights on the initial set of information. Phase III integrates, lists, aggregates and creates a leaner representation and directed to storage. The Phase IV, about data already stored dry, is intended for analysis and modeling of the relationships and always of this information. Phase $V$ is the interpretation of what has been reached in the previous stage and the fate that it goes in terms of decisions, plan of action or tracking performance according to the situation in question. Each of these Phases is represented as a specific layer because it is evidenced the complex path of processing of the data from your capture to your release to the end user. Another adaptation also occurred in relation to the initial general strategy of Big Data in three dimensions mentioned by Davenport (2014) and their immediate goals, reaching to some relevant considerations in terms of delineating the action or decision to insert:

- In Dimension 2 one adaptation of the array with aspects of Porter's competitive strategy (1980), two steps from the Hill model (1995);

- In Dimension 3 the decision criteria of Paiva et al. (2009).

This initial general strategy of Big Data with these adaptations and inserts illustrated in Table 5.

Table 5. Initial general strategy of Big Data.

\begin{tabular}{lll}
\hline \multicolumn{1}{c}{ DIMENSION } & Immediate Objective & \multicolumn{1}{c}{ Action and Decision } \\
\hline Dimension 1 & $\begin{array}{l}\text { Focus on analyzing the } \\
\text { problem in two senses }\end{array}$ & $\begin{array}{l}\text { Sense 1: capture the Big } \\
\text { Data Problem of innovation } \\
\text { or change of product or } \\
\text { services. (new) }\end{array}$ \\
& & \\
\hline
\end{tabular}


Table 5. Continued...

\begin{tabular}{|c|c|c|}
\hline DIMENSION & Immediate Objective & Action and Decision \\
\hline & & $\begin{array}{l}\text { Sense 2: dealing with data } \\
\text { from the Big Data Problem } \\
\text { of external competitive } \\
\text { news? (external new } \\
\text { situation or innovation) }\end{array}$ \\
\hline Dimension 2 & $\begin{array}{l}\text { Purpose array and stages of } \\
\text { implementation (discovery } \mathrm{x} \\
\text { production) }\end{array}$ & $\begin{array}{l}\text { Adaptation of this array with } \\
\text { aspects of the Competitive } \\
\text { Strategy of Porter (1980) } \\
\text { and the steps } 1 \text { and } 2, \text { of } \\
\text { the model of Hill (1995). }\end{array}$ \\
\hline Dimension 3 & $\begin{array}{l}\text { Quickness and } \\
\text { aggressiveness of the Big } \\
\text { Data Project deployments }\end{array}$ & $\begin{array}{l}\text { Adaptation of decision } \\
\text { criteria from Paiva et al. } \\
\text { (2009) all activities of the } \\
\text { and Value network } \\
\text { operations (RVO). }\end{array}$ \\
\hline
\end{tabular}

Source: Prepared by the authors adapting the proposal for Davenport (2014).

It is necessary to make a consideration from the 5V's Big Data proposing a general tabulation of sources and their possible characteristics to direct the use of specific tools/applications as appropriate and the need of Analysis model Data. The 5V's Matrix (Section 6.1.4), presents the overview, from the illustrative case and by the fact that there is an enormous diversity of computational tools they were not mentioned in this table intentionally, as this depends on the problem being researched at Big Data.

\subsection{Step 5 - Presentation of a conceptual framework for use and production strategy support.}

Figure 5 illustrates the General format of the proposed framework, in its 3 levels (strategic, operational, and technical) being 5 analysis and strategic actions, over 5 stages of the pipeline that are supported technically by 5 layers.

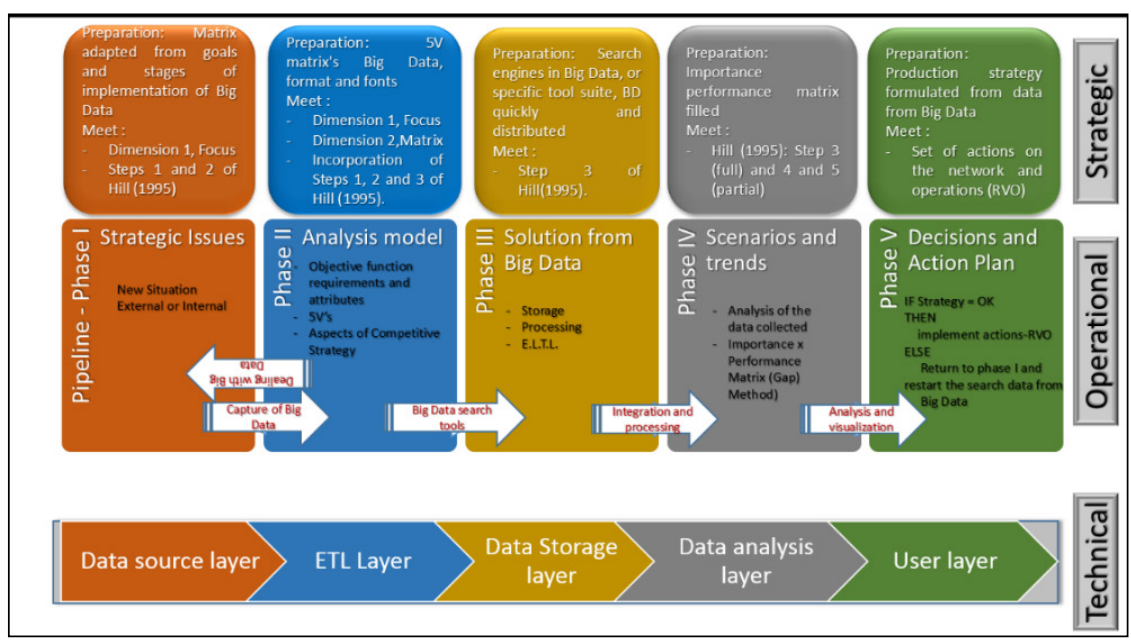

Figure 5. overview of the proposed theoretical-conceptual framework. ETL (Extract-TransformLoad); ELTL (Extract-Load-Transform-Load); RVO (Value Network Operations). 
The Table 6 presents a breakdown of the activities and actions of the framework to be made in each of the phases in the Strategic, operational and technical Levels. It is necessary to point out that when you arrive in phase $\mathrm{V}$, if there is the perception that the performance required by desired strategy still falls short of the desired level, returns to the stage I and restarts the process. It is estimated that over time and with the frequency of use of the framework this whole process is fast and dynamic, because the intention is to have agility and accuracy in strategic decisions involving operations (production).

Table 6. Details of the framework over the three levels and five stages.

\begin{tabular}{|c|c|c|c|}
\hline $\begin{array}{l}\text { Level } \\
\text { Phase }\end{array}$ & Strategic & Operational & Technical \\
\hline $\begin{array}{l}\text { Phase I } \\
\text { Strategic Issues }\end{array}$ & $\begin{array}{l}\text {-analysis of } \\
\text { opportunities (Table 3) } \\
\text {-initial general strategy } \\
\text { (Table 5): } 1 \text { Dimension } \\
\text { (Sense } 1 \text { or } 2 \text { ) and the } \\
\text { focus being } \\
\text { treated/examined } \\
\text {-analysis and definition } \\
\text { of the Steps } 1 \text { and } 2 \\
\text { from Hill (1995) }\end{array}$ & $\begin{array}{l}\text {-Array of goals and } \\
\text { stages of } \\
\text { implementation (Table 8) } \\
\text {-Set it tools to capture } \\
\text { data from Big Data as } \\
\text { defined by the Strategic }\end{array}$ & $\begin{array}{l}\text {-define what will be } \\
\text { captured the Big } \\
\text { Data-set from which } \\
\text { sources will be } \\
\text { captured data from } \\
\text { Big Data (Table 7) } \\
\text {-tier data source }\end{array}$ \\
\hline $\begin{array}{l}\text { Phase II } \\
\text { Analysis model }\end{array}$ & $\begin{array}{l}\text {-define the objective } \\
\text { function that meets the } \\
\text { dimensions } 1 \text { and } 2 \\
\text { (Table 5) beyond the } \\
\text { Focus be clear and } \\
\text { analyzed } \\
\text {-define aspects of } \\
\text { competitive strategy } \\
\text { (cost, focus or } \\
\text { differentiation) } \\
\text {-analysis, definition and } \\
\text { inclusion of Step } 3 \text { of Hill } \\
\text { (1995): winners and } \\
\text { order qualifiers } \\
\text {-define the requirements } \\
\text { and the necessary } \\
\text { attributes of the quality } \\
\text { of the information } \\
\text { sought: heterogeneity, } \\
\text { scale and temporality }\end{array}$ & $\begin{array}{l}\text {-capture and process } \\
\text { the data of the Big Data } \\
\text { defined and classified } \\
\text { in the } 5 \mathrm{~V} \text { 's } \mathrm{x} \\
\text { format/data source } \\
\text { (Table } 7 \text { ) } \\
\text {-follow the array of } \\
\text { goals and stages of } \\
\text { implementation } \\
\text { (Table } 8 \text { ) }\end{array}$ & $\begin{array}{l}\text {-define the tools and } \\
\text { software } \\
\text { applications for ETL } \\
\text { (extract-transform- } \\
\text { load) Big Data } \\
\text {-data ETL Layer }\end{array}$ \\
\hline $\begin{array}{l}\text { Phase III } \\
\text { Solution from } \\
\text { the Big Data }\end{array}$ & $\begin{array}{l}\text {-Resume review with } \\
\text { the staff about what } \\
\text { mechanisms will be } \\
\text { used for the search in } \\
\text { Big Data in order to } \\
\text { meet adequately the } \\
\text { appearance set for } \\
\text { competitive strategy } \\
\text {-Resume analysis of } \\
\text { order winners and order } \\
\text { qualifiers (Step } 3 \text { of Hill } \\
\text { (1995)) }\end{array}$ & $\begin{array}{l}\text {-searches in Big Data x } \\
\text { Group on strategic clusters. } \\
\text {-E.L.T.L.-Extract (various } \\
\text { sources), Load (Data Base } \\
\text { systems } \\
\text {-NoSql and Hadoop } \\
\text { Distributed File System - } \\
\text { HDFS), Trasform (reduce } \\
\text { + filter), Load (transform } \\
\text { unstructured and } \\
\text { structured - joinned } \\
\text { results). } \\
\text {-solid storage strategy or } \\
\text { upon request of the } \\
\text { Manager }\end{array}$ & $\begin{array}{l}\text {-set as the storage } \\
\text { and processing of } \\
\text { the data collected } \\
\text { from the Big Data } \\
\text {-Data Storage layer }\end{array}$ \\
\hline
\end{tabular}


Table 6. Continued...

\begin{tabular}{|c|c|c|c|}
\hline $\begin{array}{l}\text { Level } \\
\text { Phase }\end{array}$ & Strategic & Operational & Technical \\
\hline $\begin{array}{l}\text { Phase IV } \\
\text { Scenarios and } \\
\text { trends }\end{array}$ & $\begin{array}{l}\text { - Matrix Importance- } \\
\text { Performance (urgent } \\
\text { action zone, } \\
\text { improvement zone) } \\
\text { (Figure 6) } \\
\text { - Definition of processes } \\
\text { to produce and deliver } \\
\text { products (Step } 4 \text { of Hill } \\
\text { (1995)) } \\
\text { - Definition of the } \\
\text { necessary infrastructure } \\
\text { for the new operational } \\
\text { actions (Step } 5 \text { of Hill } \\
\text { (1995)) }\end{array}$ & $\begin{array}{l}\text {-Analysis of the data } \\
\text { collected from the Big } \\
\text { Data and categorized in } \\
\text { the Importance- } \\
\text { Performance (Gap) }\end{array}$ & $\begin{array}{l}\text {-preparation of the } \\
\text { data in appropriate } \\
\text { formats for decision } \\
\text { making } \\
\text {-data analysis Layer }\end{array}$ \\
\hline $\begin{array}{l}\text { Phase V } \\
\text { Decisions and } \\
\text { Action Plan }\end{array}$ & $\begin{array}{l}\text {-Formulation of } \\
\text { production strategy from } \\
\text { what was identified in } \\
\text { phase IV as priority } \\
\text { improvement actions- } \\
\text { set the deadline for } \\
\text { evaluating the strategy } \\
\text {-Define how the actions } \\
\text { will be managed and } \\
\text { how they will be } \\
\text { measured their } \\
\text { performances } \\
\text {-IF Strategy formulated } \\
=\text { Ok } \\
\text { THEN Implement } \\
\text { actions-RVO ELSE } \\
\text { return to phase I and } \\
\text { restart the search data } \\
\text { from Big Data }\end{array}$ & $\begin{array}{l}\text {-implementation of } \\
\text { actions planned for the } \\
\text { production strategy } \\
\text { formulated and Value } \\
\text { network operations } \\
\text { (RVO), namely, what } \\
\text { decisions will be taken } \\
\text { on each one of the } \\
\text { activities (Table 9) }\end{array}$ & $\begin{array}{l}\text {-Mount dashboard } \\
\text { for monitoring the } \\
\text { actions planned } x \\
\text { performance } \\
\text {-Users layer }\end{array}$ \\
\hline
\end{tabular}

Source: prepared by the authors.

\section{Stage 3: Illustrative application of the conceptual framework on the SAAE-SC}

The analysis used the Presidency as business strategist/decision-makers and operations management and services (GOS) that is responsible for field operations in terms of construction, maintenance and network losses control. So, the formulation of the strategy of production will pass by the Presidency and the GOS should run it and report the due advances, delays, performance problems, among others. From that definition will be described and detailed application of the framework proposed in its 5 Phases.

\subsection{PHASE I - Strategic issues}

\subsection{2 \# Strategic level}

- Opportunity analysis (Table 3) and of the initial strategy of the Big Data (Table 5) with the array of goals and stages of implementation of Big Data (Table 7). 
- Sets in 1 Dimension focus application (internal sense, i.e. with the same crew and the same resources available to get be more assertive in repairs extending interventions network)-make sense new intern from the external information of Big Data.

- The intended Focus is to follow the goal announced by the Presidency of the SAAE-SC that in 2018 the leaks will be cleared in your entirety.

- Steps of Hill (1995):

o Step 1 - definition of corporate objectives for the Presidency in relation to supplies, services, production, distribution and Services aggregates, i.e. extinction of leaks and gradual renewal of the primary and secondary network.

o Step 2 - definition of marketing strategy in order to stimulate the participation of taxpayers in the channels of communication with the SAAE-SC to an ER with quality and excellence in service provided for the extinction of leaks and the renewal of the network primary and secondary.

\subsection{3 \# Operational level}

- Define matrix of goals and stages of implementation (Table 8)

- Set it tools to capture data from Big Data as defined by the Strategic level

\subsection{4 \# Technical level}

Define what will be captured and what sources will be used (Table 7).

Table 7. 5V's Matrix versus format and data source of Big Data.

\begin{tabular}{|c|c|c|c|c|c|c|c|c|c|c|}
\hline \multirow[b]{2}{*}{$\begin{array}{c}\text { Format } \\
\text { Source } \\
5 V ' s\end{array}$} & \multicolumn{3}{|c|}{ Structured } & \multicolumn{3}{|c|}{ Semi Structured } & \multicolumn{4}{|c|}{ Not Structured } \\
\hline & 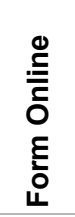 & 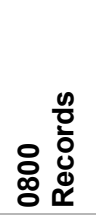 & 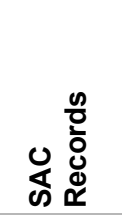 & $\begin{array}{l}\frac{1}{0} \\
\frac{0}{10} \\
\frac{0}{0} \\
\frac{0}{0} \frac{0}{0} \\
\frac{3}{2} \\
\frac{2}{0}\end{array}$ & 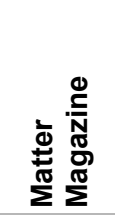 & $\begin{array}{l}\frac{c}{\pi} \\
\frac{E}{0} \\
\frac{0}{0} \\
\frac{\partial}{0} \\
\text { है }\end{array}$ & $\begin{array}{l}\frac{0}{2} \\
\frac{1}{5} \\
\frac{0}{\pi} \\
\frac{1}{3}\end{array}$ & 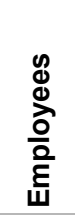 & $\begin{array}{l}\frac{1}{0} \\
\frac{0}{\pi} \\
\frac{0}{00} \\
\frac{3}{0} \\
\frac{1}{E} \\
\geq\end{array}$ & 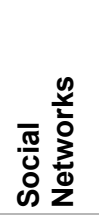 \\
\hline Volume & $15 \%$ & $10 \%$ & $\begin{array}{c}532 / \text { yea } \\
r\end{array}$ & $\begin{array}{c}10 / \\
\text { year }\end{array}$ & $\begin{array}{c}5 / \\
\text { year }\end{array}$ & relative & relat & $35 \%$ & $\begin{array}{l}36 / \\
\text { year }\end{array}$ & $\begin{array}{l}180 / \\
\text { year }\end{array}$ \\
\hline Variety & high & high & high & specific & specific & high & relat & high & specific & high \\
\hline Velocity & $24 \mathrm{~h}$ & $24 \mathrm{~h}$ & $24 \mathrm{~h}$ & N/A & $\mathrm{N} / \mathrm{A}$ & $24 \mathrm{~h}$ & relat & $<\mathrm{t}$ & relative & $24 \mathrm{~h}$ \\
\hline Veracity & high & high & high & relative & relative & high & relat & relat & attentiona & attention \\
\hline Value & high & high & high & relative & relative & high & relat & relat & high & high \\
\hline $\begin{array}{c}\text { Tools } \\
\text { Big Data }\end{array}$ & & & & tion tools & $s$, loduming & , process & $\mathrm{ng} / \mathrm{cle}$ & . nge ne & w load & \\
\hline
\end{tabular}

Source: prepared by the authors. 


\subsection{PHASE II - Analysis model}

\subsection{1 \# Strategic level}

- Objective function: to identify as quickly as possible the biggest leaks, that rely on multidisciplinary team specialized higher and identifying if that stretch of the network has been updated (reformed central pipe with all branches reformed and rebound);

- Analysis, definition and inclusion of Step 3 of Hill (1995): order qualifiers criteria $x$ order winners. For this application the criteria related to compliance with qualifiers to that is the Mission of the SAAE-SC, namely, providing services of water and sewage treatment with quality at a fair price. The order winners are the most important aspects in determining the competitive position of the company and must be continuously reviewed by the Presidency of the SAAE-SC, mainly in relation to critical points raised in phase IV (action zone urgent and improvement);

- Requirements and attributes: frequency of repetition of the taxpayer information crossing with the severity of the leak in the overall result of the primary and secondary network;

- Aspects of competitive strategy: each time it is identified a large proportion must be done an analysis whether it is possible to adjust the net over 100 meters. This implies the possible reform and rewiring of supply of homes, shops and services. These implications should be examined, if it is possible to accomplish this renewal of 100 meters in this big spill correction service, over the course of a week, you can design every 10 interventions that were possible with this multidisciplinary team specialized, so that means over 1 month could renew about of 4,400 km/year, whereas in December there is a lot of rain which would make this work. The Dimension 2 provides an matrix (Table 8) against the backdrop of the three aspects of a generic competitive strategy (costs, focus or differentiation) observed in crosses between goals of value from the Big Date with the stages of implementation identifying possible discovery and planning your production. It is necessary to highlight that as has been advocated by Porter generic competitive strategy directs for one of the three aspects and not by the three at the same time. In this case, the array was completed on three points by way of illustration in a formatting possibilities as a checklist for each of the three aspects (costs, focus or differentiation).

Table 8. Dimension 2 matrix of goals and stages of Implementation from the Big Data.

\begin{tabular}{|c|c|c|c|c|c|}
\hline \multirow{2}{*}{$\begin{array}{c}\text { Competitive } \\
\text { Strategy }\end{array}$} & \multirow{2}{*}{$\begin{array}{c}\text { Stages of } \\
\text { Implementation } \\
\text { Objectives } \\
\text { of value }\end{array}$} & \multicolumn{2}{|c|}{ DISCOVERIES } & \multicolumn{2}{|c|}{ PRODUCTION } \\
\hline & & What? & Who? & What? & Who? \\
\hline 占 & Download Costs & $\begin{array}{l}\text {-identification of } \\
\text { the problem to be } \\
\text { treated } \\
\text {-best practices } \\
\text {-alternative } \\
\text { materials } \\
\text {-new training } \\
\text { schemes }\end{array}$ & 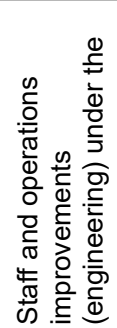 & $\begin{array}{l}\text {-analysis of } \\
\text { scenarios and } \\
\text { possibilities } \\
\text {-standardized } \\
\text { work with best } \\
\text { practices, new } \\
\text { materials and kits } \\
\text { and ideas viable } \\
\text { control of } \\
\text { contributors }\end{array}$ & 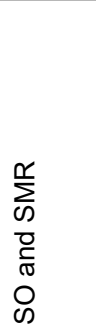 \\
\hline
\end{tabular}


Table 8. Continued...

\begin{tabular}{|c|c|c|c|c|c|}
\hline \multirow{2}{*}{$\begin{array}{l}\text { Competitive } \\
\text { Strategy }\end{array}$} & \multirow{2}{*}{$\begin{array}{c}\text { Stages of } \\
\text { Implementation } \\
\text { Objectives } \\
\text { of value }\end{array}$} & \multicolumn{2}{|c|}{ DISCOVERIES } & \multicolumn{2}{|c|}{ PRODUCTION } \\
\hline & & What? & Who? & What? & Who? \\
\hline & & $\begin{array}{l}\text {-development of } \\
\text { repair kits and } \\
\text { devices } \\
\text {-ideas of } \\
\text { contributors }\end{array}$ & & & \\
\hline & $\begin{array}{l}\text { Decisions faster } \\
\text { (less Time) }\end{array}$ & $\begin{array}{l}\text {-data collections } \\
\text { focused on major } \\
\text { problems occurred } \\
\text { analyzing them } \\
\text { quickly generating } \\
\text { action plans } \\
\text {-search of } \\
\text { alternative } \\
\text { investments with a } \\
\text { focus on strategic } \\
\text { goals } \\
\text {-systematization of } \\
\text { the workflow of } \\
\text { information } \\
\text { collected } x \\
\text { decision }\end{array}$ & 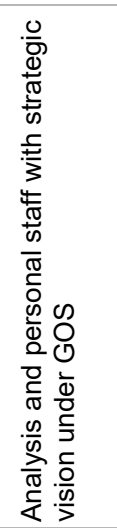 & $\begin{array}{l}\text { operationalization } \\
\text { of the main } \\
\text { problems listed in } \\
\text { the plans of action } \\
\text {-use of alternative } \\
\text { investments } \\
\text {-using the new } \\
\text { workflow of } \\
\text { information } \\
\text { collected and the } \\
\text { decision taken } \\
\text { from it }\end{array}$ & 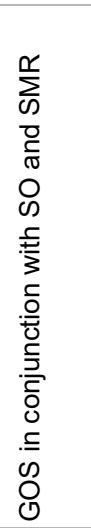 \\
\hline $\begin{array}{l}\infty \\
\text { ల } \\
\text { О } \\
\end{array}$ & $\begin{array}{l}\text { Better decisions } \\
\text { (focus-objectivity) } \\
\text { (greater } \\
\text { assertiveness) }\end{array}$ & $\begin{array}{l}\text {-diversity of } \\
\text { collected data x } \\
\text { scenarios analyzed } \\
\text { - historical series of } \\
\text { the main problems } \\
\text { in the main regions } \\
\text { of the city } \\
\text { - trend analysis of } \\
\text { key measures and } \\
\text { action plans } x \\
\text { results }\end{array}$ & 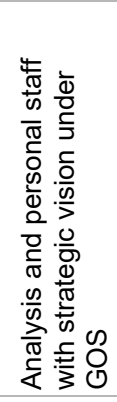 & $\begin{array}{l}\text { - scenarios } \\
\text { examined } \\
\text { generating actions } \\
\text { of improvements } \\
\text { in operations } \\
\text { - activities } \\
\text { directed to certain } \\
\text { problems in } \\
\text { certain regions } \\
\text { - systematisation } \\
\text { of feedback from } \\
\text { plans developed }\end{array}$ & 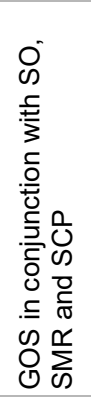 \\
\hline 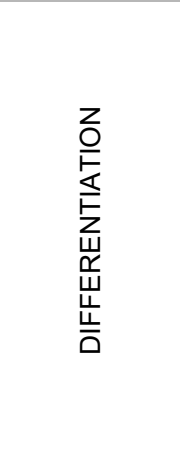 & $\begin{array}{l}\text { Product and } \\
\text { service innovation }\end{array}$ & $\begin{array}{l}\text { - control system of } \\
\text { telemetry and } \\
\text { remote control of } \\
\text { sanitation } \\
\text { - more modern and } \\
\text { effective } \\
\text { hydrometers } \\
\text { - intelligent } \\
\text { monitoring system } \\
\text { across the various } \\
\text { data sources }\end{array}$ & 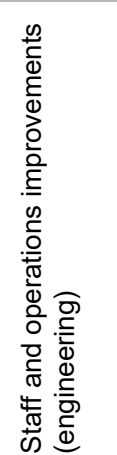 & $\begin{array}{l}\text { - online data } \\
\text { about the filling } \\
\text { stations both in } \\
\text { relation to } \\
\text { operational } \\
\text { information about } \\
\text { techniques } \\
\text { - hydrometers } \\
\text { exchange plan } \\
\text { every } 5 \text { years } \\
\text { - Big Data } \\
\text { application to be } \\
\text { developed and } \\
\text { deployed }\end{array}$ & 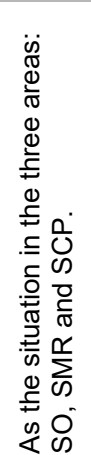 \\
\hline
\end{tabular}

Source: prepared by the authors ${ }^{*}$. GOS (Works and Sanitation); SO (Works), SMR (Maintenance of Networks), SCP (Control of Losses).

\subsection{2 \# Operational level}

- Capture and process the data of the Big Data defined and classified in 5V's Matrix versus format/Source (Table 7);

- Then the array of goals and stages of implementation (Table 8). 


\subsection{3 \# Technical level}

- Define tools and software applications for data ETL of Big Data.

\subsection{Phase III - Solution from the Big Data}

\subsection{1 \# Strategic level}

- Resume review with the staff about the search engines in Big Data as competitive strategy adopted (cost, focus or differentiation).

- Resume analysis of order winners and qualifiers criteria in order to identify possible ruptures and misunderstandings by reviewing the data to date approaches.

\subsection{2 \# Operational level}

- With the array 5V's defined in the previous phase, alongside the objective function and the requirements/attributes, now enter the it aspects involving the search of information tools of Big Data, grouping them into clusters that make sense and cater to what was strategic defined. Are four sub-phases-E.L.T.L.-Extract (various sources), Load (DB systems-NoSql and HDFS), Trasform (reduce + filter), Load (transform unstructured and structured - joinned results). A strategy of continuous storage or under the Manager's request must be made in order to register in the database the diverse sources of information already identified in phase II, which should be prioritized to meet the strategic aspect to be parsed in scenarios.

- Continuous data storage strategy sought in Big Data or under the Manager's request for ad-hoc analysis.

\subsection{Phase IV - Scenarios and trends}

\subsection{1 \# Strategic level}

- Preparation of the importance-performance matrix (GAP Method), illustrated in Figure 6 , prioritizing the actions on what is identified as urgent action zone or area of improvement.

- From the client's vision for the importance analysis on scale of 1 to 3 (of order), of 4 to 5 (order qualifier), of 7 to 9 . These data could be processed online service, 0800 , social networks, journalistic materials, or online polls on specific websites or via search companies, to obtain external information about perceptions of the presence of the SAAE-SC along the community. Performance analysis has to do with competitors who, in this case, may be other public services similar to other municipalities of the same with published data that are equal or superior, servicing of benchmarking as well as private companies provide these outsourced services in other cities and who publish their data and to make disclosure and marketing materials. For this analysis the importance scale is 1 to 3 based services "are better than" of 4 to 6 the services "are the same as" by 7 to 9 services "are worse than". 


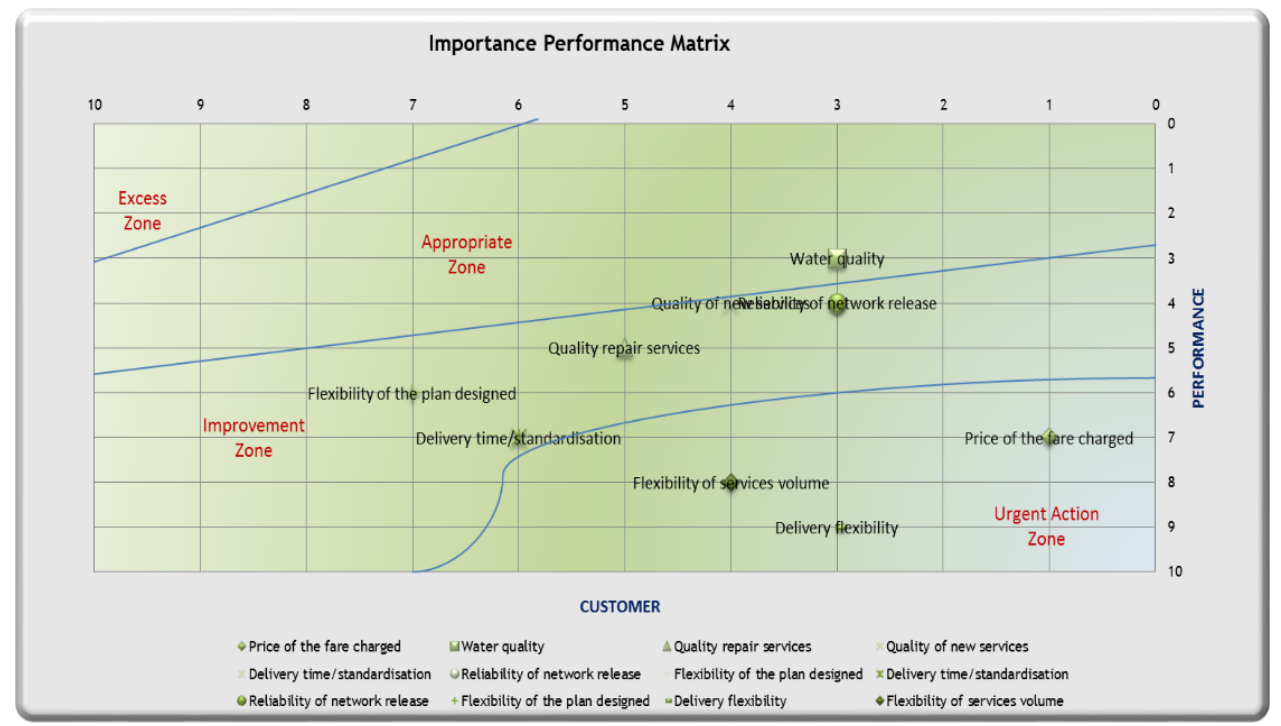

Figure 6. importance x performance Matrix (GAP Method). Source: prepared by the authors.

- Definition of processes to produce and deliver products (step 4 of Hill (1995)) from the array analysis importance $x$ performance (Figure 6):

a) The performance objectives adopted for this illustration are: price of the fare charged, water quality, quality repair services, quality of services, delivery/standardization, reliability network release, flexibility of the plan designed, flexibility, flexibility in the volume of services.

b) By lifting the urgent action Area must be prioritized in relation to: i) price of the fare charged; ii) flexibility of network delivery working; iii) flexibility in the volume of services. So, the decision maker/Manager SAAE-SC from that matrix Importance-Performance watching what is present in the urgent action, should make decisions to try to reverse this situation, what from the actions taken could be again measured by Big Data and data again are tabulated in this array.

c) In a second moment, the area of improvements (or improve) should also be considered by the decision maker/Manager SAAE -SC, in order to plan actions to mitigate the objectives we are composing briefly this matrix region. Also, from the actions implemented again there could be a measurement by Big Data and data be tabulated in the array.

\subsection{2 \# Operational level}

Analysis of the data collected from the Big Data and categorized in the array $x$ performance importance (GAP), illustrated in Figure 6, writing scenarios for decisions.

\subsection{3 \# Technical level}

Preparation of the data collected in appropriate formats for decision making. 


\subsection{Phase V - Decisions and action plan}

\subsection{1 \# Strategic level}

- Formulation of production strategy from what was identified in phase IV of which actions will be priorities for improvement defining how these actions will be managed in the value Network and operations (RVO), illustrated in Table 9, whereas the Decision-making aspect and the column of possible decisions;

- Set the deadline for reassessing the strategy adopted;

- Define how they will be measured the performance of the actions taken;

- Verification that production strategy adopted is the satisfaction, otherwise reboot in Phase I on.

\subsection{2 \# Operational level}

- Implementation of the actions planned for the production strategy formulated in RVO (Table 9) mindful of the column of points to consider;

- Formulation of production strategy from what was identified in phase IV as priority actions for improvement.

Table 9. decisions and Action plan - possible and to consider.

\begin{tabular}{|c|c|c|}
\hline Decision-making Aspect & Possible Decisions & Points to consider \\
\hline Supplies & $\begin{array}{l}\text { - number of suppliers } x \\
\text { purchased item } \\
\text { - type of relationship with } \\
\text { supplier } \\
\text { - partnerships } \\
\text { - subcontracting of } \\
\text { activities }\end{array}$ & $\begin{array}{l}\text { Bills of materials (bids), } \\
\text { machinery and equipment } \\
\text { allocation, allocation of people } \\
\text { (team). }\end{array}$ \\
\hline $\begin{array}{l}\text { Product/Service } \\
\text { Development }\end{array}$ & $\begin{array}{l}\text { - management } \\
\text { - technologies and } \\
\text { infrastructure teams own } \\
\text { - usage level you } \\
\text { - level of integration with } \\
\text { partners }\end{array}$ & $\begin{array}{l}\text { Detailed action plan for } \\
\text { implementation of the service, } \\
\text { by evaluating the local impacts } \\
\text { on primary or secondary } \\
\text { network, water and sewage } \\
\text { systems. }\end{array}$ \\
\hline Execution/Production & $\begin{array}{l}\text { - total production capacity } \\
\text { - planned level x used } \\
\text { - strategies in seasonality } \\
\text { - purchase of technology } \\
\text { and equipment } \\
\text { - level of innovation in } \\
\text { processes } \\
\text { - profile required of the } \\
\text { professionals * search for } \\
\text { continuous improvement }\end{array}$ & $\begin{array}{l}\text { Implementation of the detailed } \\
\text { action plan, with appropriate } \\
\text { term deadline with } \\
\text { contingencies, as the situation } \\
\text { by starting the services. }\end{array}$ \\
\hline Distribution & $\begin{array}{l}\text { - level of customization of } \\
\text { services and products } \\
\text { - systems or outsourced- } \\
\text { network and reservoirs } \\
\text { - level of use of the internet } \\
\text { and you }\end{array}$ & $\begin{array}{l}\text { Back to normal mains water } \\
\text { supply to the taxpayers. }\end{array}$ \\
\hline
\end{tabular}


Table 9. Continued...

Proposal for a framework for production...

\begin{tabular}{lll}
\hline Decision-making Aspect & \multicolumn{1}{c}{ Possible Decisions } & \multicolumn{1}{c}{ Points to consider } \\
\hline Aggregate services & $\begin{array}{l}\text { - type of service to be } \\
\text { added to the product or } \\
\text { service offered }\end{array}$ & $\begin{array}{l}\text { Other services that may be } \\
\text { required depending on the } \\
\text { - form of service operations } \\
\text { management }\end{array}$ \\
& $\begin{array}{l}\text { com the action plan and/or } \\
\text { - speed, level of } \\
\text { customization and }\end{array}$ & \\
& localization of service \\
& offered & \\
\hline
\end{tabular}

Fonte: elaborado pelos autores.

\subsection{3 \# Technical level}

- Dashboard mount (Panel Management) for the monitoring of the planned actions $x$ performance.

As mentioned in the strategic Level of this phase $\mathrm{V}$, the results, check that the strategy adopted has reached expected levels then continue to perform the current Action Plan, otherwise return to phase I performing the step-by-step of each of the Subsequent phases until you reach this point on a new formulation of strategy and subsequent evaluation of the same.

For example, some comparative projections could be made to a problem or situation to solve/forward, the current strategy and a strategy formulated by using the framework. The current strategy is based on what the President of SAAE-SC stated in interviews mentioning some goals that should be achieved between the years 2017 and 2018 . The Table 10 presents these comparative projections.

Table 10. comparative projections between current $x$ strategy using strategy framework.

\begin{tabular}{|c|c|c|}
\hline $\begin{array}{l}\text { Problem or } \\
\text { situation }\end{array}$ & Current strategy & Using strategy framework \\
\hline Leaks & $\begin{array}{l}\text { Average of } 10 \text { to } 15 \text { new leaks per } \\
\text { day, between } 300 \text { and } 450 \text { leaks } \\
\text { per month throughout the city, with } \\
\text { about } 20 \text { leaks/day. }\end{array}$ & $\begin{array}{l}\text { The speed of detection, it is estimated } \\
\text { that it will be possible to reduce by } \\
50 \% \text { the leaks by the gradual removal } \\
\text { of } 100 \text { m snippets of old pipe. }\end{array}$ \\
\hline $\begin{array}{l}\text { Age and size of the } \\
\text { primary and } \\
\text { secondary network } \\
\text { pipe }\end{array}$ & $\begin{array}{l}\text { About } 30 \text { years of approximately } \\
50 \mathrm{~km} \text {, designed in } 2018 \text { with own } \\
\text { resources replacing the } 43 \mathrm{~km} \text { taking } \\
\text { around } 17 \text { years for total renovation. }\end{array}$ & $\begin{array}{l}\text { Scheduled replacement of about } \\
400 \mathrm{~m} / \mathrm{month} \text { projecting a total of } \\
4,400 \mathrm{~m} / \text { year, around } 13 \text { years } \\
\text { for total renovation. }\end{array}$ \\
\hline Reservoirs & $\begin{array}{l}\text { There are } 29 \text { large reservoirs } \\
\text { already operational and project } \\
\text { the installation of } 6 \text { smaller } \\
\text { reservoirs to meet the critical } \\
\text { points of water supply. }\end{array}$ & $\begin{array}{l}\text { The design with the lack of data } \\
\text { and supply your localized } \\
\text { recurrence. }\end{array}$ \\
\hline Sewage treatment & $\begin{array}{l}\text { Currently, } 98 \% \text { of all city sewage } \\
\text { treatment, the goal is to wrap up } \\
\text { with } 100 \% 2018 \text { Treaty. }\end{array}$ & $\begin{array}{l}\text { Designing with data from future } \\
\text { expansions of urban and } \\
\text { industrial zoning of the city. }\end{array}$ \\
\hline
\end{tabular}

Source: prepared by the authors. 


\section{Final considerations}

This article sought to answer the question of research establishing a structured way to support production strategy with use of aspects of processing of data from Big Data showing a proposal for a framework.

To reach the framework proposed two stages. In step 15 steps were carried out research and bibliographical analysis on production strategy and Big Data with the aim of reaching Step 2 , that via other 5 steps are elaborated the proposal of a theoretical-conceptual framework. In a third step an illustrative application in a public service trying to align the strategy of production of services with the available data sources.

There was a projection of services to be performed from some generic analysis of data recorded from the institutional website, information from interviews granted to newspapers and a scan on social networks (facebook).

Illustrative application generated an expectation of continuity and search for technological means to check on how long the main problems would be resolved and what degree of economics from this deployment.

The main contribution was the systematization of an unpublished and original proposal at the moment.

Nevertheless, this proposal lacks more detailed field application in industrial or trade companies aiming at possible new tweaks and improvements, being this a limitation of the paper. However, to the simplification of your structure to promote understanding if not prescribe any kind of prior technological tooling getting it in charge of the strategic review and the expertise of the team involved. For future work is the application of the framework proposed in industrial and trade companies, analyzing the similarities and differences of the results and the possible needs of tweaks and improvements.

\section{Acknowledgements}

We register our thanks to the institutions in which we work, which enabled the results of this research through sabbatical (UNIMEP) and authorisation of orientation (UFSCar), post-doctoral stage.

\section{References}

Agrawal, D., Bernstein, P., Bertino, E., Davidson, S., \& Dayal, U. (2011). Challenges and opportunities with Big Data 2011-1. West Lafayette: Purdue University. Purdue e-Pubs. Cyber Center Technical Reports. Retrieved in 2016, March 22, from http://docs.lib.purdue.edu/cctech/1

Akter, S., \& Wamba, S. F. (2016). Big Data analytics in e-commerce: a systematic review and agenda for future research. Electronic Markets, 26(2), 173-194. http://dx.doi.org/10.1007/s12525-016-0219-0.

Akter, S., Wamba, S. F., Gunasekaran, A., Dubey, R., \& Childe, S. J. (2016). How to improve firm performance using Big Data analytics capability and business strategy alignment? International Journal of Production Economics, 182, 113-131. http://dx.doi.org/10.1016/j.jpe.2016.08.018.

Brown, B., Chui, M., \& Manyika, J. (2011). Are you ready for the era of 'Big Data'? The McKinsey Quarterly, 4(1), 24-35.

Campos, F. R. (2015). The management innovation in knowledge-intensive services: opportunities and challenges of Big Data (Masters Dissertation). Instituto de Geociências, Universidade Estadual de Campinas, Campinas. 
Chase, R. B., Jacobs, F. R., \& Aquilano, N. (2003). Operations management for competitive advantage (10th ed.). McGraw Hill.

Davenport, T. H. (2014). Big Data at work: dispelling the myths, uncovering the opportunities. EUA: Harvard Business School Press. http://dx.doi.org/10.15358/9783800648153.

Davenport, T. H., Barth, P., \& Bean, R. (2012). How Big Data is different. MIT Sloan Management Review, 54(1), 43.

Dubey, R., Gunasekaran, A., Childe, S. J., Wamba, S. F., \& Papadopoulos, T. (2015). The impact of Big Data on world-class sustainable manufacturing. International Journal of Advanced Manufacturing Technology, 84(1-4), 631-645. http://dx.doi.org/10.1007/s00170015-7674-1.

Haddara, M., \& Elragal, A. (2015). The readiness of ERP systems for the factory of the future. Procedia computer science (pp. 721-728). USA: Elsevier. http://dx.doi.org/10.1016/j.procs.2015.08.598.

Halper, F., \& Krishnan, K. (2013). TDWI Big Data maturity model guide: interpreting your assessment score. TDWI Benchmark Guide 2013-2014 (20 p.). Europe: TDWI.

Hayes, R. H., \& Whellwright, S. C. (1984). Restoring our competitive edge: competing through manufacturing. New York: Free.

Hayes, R. H., Pisano, G., Upton, D., \& Whellwright, S. C. (2004). Operation, strategy and technology: pursuing the competitive edge. Nova Jersey: Wiley.

Hill, T. (1995). Manufacturing strategy: text and cases. London: MacMillan Business. http://dx.doi.org/10.1007/978-1-349-13724-4.

Hörte, S. A., Lindberg, P., \& Tunalv, C. (1987). Manufacturing strategies in Sweden. International Journal of Production Research, 25(11), 1573-1586.

Information Systems Audit and Control Association - ISACA. (2016). Big Data: impacts and benefits. Retrieved in 2016, March 22, from http://www.isaca.org/KnowledgeCenter/Research/ResearchDeliverables/Pages/Big-Data-Impacts-and-Benefits.aspx

International Business Machines - IBM. (2016). What is Big Data? Bringing Big Data to enterprise. Retrieved in 2016, March 22, from http://www.ibm.com/software/data/bigdata

Jelinek, M., \& Bergey, P. (2013). Innovation as the strategic driver of sustainability: big Data knowledge for profit and survival. IEEE Engineering Management Review, 41(2), 14-22. http://dx.doi.org/10.1109/EMR.2013.2259978.

Johnson, G., Scholes, K., \& Whittington, R. (2009). Fundamentals of strategy. Nova Jersey: Prentice Hall.

Kagermann, H., Wahlster, W., \& Helbig, J. (2013). Recommendations for implementing the strategic initiative industrie 4.0. Final report of the Industrie 4.0 Working Group (p. 82). Frankfurt: Acatech.

Kambatla, K., Kollias, G., Kumar, V., \& Grama, A. (2014). Trends in Big Data analytics. Journal of Parallel and Distributed Computing, 74(7), 2561-2573. http://dx.doi.org/10.1016/j.jpdc.2014.01.003.

Lii, D., Tang, H., Wang, S.,\& Liu, C. (2017). A big data enabled load-balancing control for smart manufacturing of Industry 4.0. Cluster Comput, 20, 1855-1864. http://dx.doi.org/10.1007/s10586-017-0852-1.

Lee, J., Kao, H.-A., \& Yang, S. (2014). Service innovation and smart analytics for Industry 4.0 and big data environment. PROCEDIA CIRP, 16, 3-8. http://dx.doi.org/10.1016/j.procir.2014.02.001.

Liu, C.-H. (2015). A conceptual framework of analytical CRM in Big Data age. International Journal of Advanced Computer Science \& Applications, 1(6), 149-152.

http://dx.doi.org/10.14569/IJACSA.2015.060620. 
Mayer-Schönberger, V., \& Cukier, K. (2013a). Big Data: a revolution that will transform how we live, work, and think. Reino Unido: Houghton Mifflin Harcourt.

Mayer-Schönberger, V., \& Cukier, K. (2013b). Big Data: how to extract volume, variety, speed and value of the avalanche of everyday information. Rio de Janeiro: Elsevier.

McAfee, A., \& Brynjolfsson, E. (2012, October). Big Data: the management revolution. Harvard Business Review, 1-9.

Meyer, A., Nakane, J., Miller, J. G., \& Ferdows, K. (1989). Flexibility: the next competitive battle: the manufacturing survey. Strategic Management Journal, 10(2), 135-144. http://dx.doi.org/10.1002/smj.4250100204.

Mills, J., Platts, K., \& Gregory, M. (1995). A framework for the design of manufacturing strategy processes: a contingency approach. International Journal of Operations \& Production Management, 15(4), 17-49. http://dx.doi.org/10.1108/01443579510083596.

Novo, R. F. (2014). Improvement in the companies ' competitive dimensions through the use of Big Data (Dissertação de mestrado). CEETPS, São Paulo.

Olofson, C. W., Villars, R. L., \& Eastwood, M. (2011). Big Data: what it is and why you should care. IDC Analyze the future. Retrieved in 2016, March 22, from http://www.idc.com

Paiva, E. L., Carvalho, J. M., Jr., \& Fensterseifer, J. E. (2009). Production and operations strategy: concepts, best practices, vision of the future (2nd ed.). Porto Alegre: Bookman.

Porter, M. E. (1980). Competitive strategy: techniques for analyzing industries and competitors. New York: Free Press.

Santos, M. Y., Sá, J. O., Andrade, C., Lima, F. V., Costa, E., Costa, C., Martinho, B., \& Galvão, J. (2017). A Big Data system supporting Bosch Braga Industry 4.0 strategy. International Journal of Management, 37, 750-760.

Seo, W., Kim, N., \& Choi, S. (2016). Big Data framework for analyzing patents to support strategic R\&D planning. In Proceedings of the 14th International Conference on Dependable, Autonomic and Secure Computing; 14th International Conference on Pervasive Intelligence and Computing; Proceedings of the 2nd International Conference on Big Data Intelligence and Computing and Cyber Science and Technology Congress (pp. 746-753). USA: IEEE.

Sheng, J., Amankwah-Amoah, J., \& Wang, X. (2017). A multidisplinary perspective of Big Data in management research. International Journal of Production Economics, 191, 97-112. http://dx.doi.org/10.1016/j.ijpe.2017.06.006.

Siddiqa, A., Hashem, I. A. T., Yaqoob, I., Marjani, M., Shamshirband, S., Gani, A., \& Nasaruddin, F. (2016). A survey of Big Data management: taxonomy and state-the-art. Journal of Network and Computer Applications, 71, 151-166. http://dx.doi.org/10.1016/j.jnca.2016.04.008.

Sivarajah, U., Kamal, M. M., Irani, Z., \& Weerakkody, V. (2017). Critical analysis of Big Data challenges and analytical methods. Journal of Business Research, 70, 263-286. http://dx.doi.org/10.1016/j.jbusres.2016.08.001.

Slack, N., \& Lewis, M. (2002). Operations strategy (2nd ed.). London: Pearson Education Lt.

Slack, N., Brandon-Jones, A., Johnston, R., \& Betts, A. (2015). Operations and processes management - principles and practice for strategic impact (4th ed). London: Pearson Education Lt.

Slack, N., Chambers, S., Harland, C., Harrison, A., \& Johnston, H. (1995). Operations management. London: Pitman Publishing.

Theorin, A., Bengtsson, K., Provost, J., Lieder, M., Johnsson, C., Lundholm, T., \& Lennartson, B. (2016). An event-driven manufacturing information system architecture for industry 4.0. International Journal of Production Research, 55(5), 1297-1311. https://doi.org/10.1080/00207543.2016.1201604. 
Turrioni, J. B., \& Mello, C. H. P. (2012). Research methodology in production engineering: strategies, methods and techniques for conducting quantitative and qualitative research. Itajubá: UNIFEI.

Vögler, M., Schleicher, J. M., Inzinger, C., Dustdar, S., \& Ranjan, R. (2016). Migrating smart city applications to the cloud. In Proceedings of the IEEE Cloud Computing (pp. 80-87). USA: IEEE. http://dx.doi.org/10.1109/MCC.2016.44.

Wamba, S. F., Akter, S., Edwards, A., Chopin, G., \& Gnanzou, D. (2015). How 'Big Data' can make big impact: findings from a systematic review and a longitudinal case study. International Journal of Production Economics, 165, 234-246. http://dx.doi.org/10.1016/j.ijpe.2014.12.031.

Wamba, S. F., Gunasekaran, A., Akter, S., Ren, S. J., Dubey, R., \& Childe, S. J. (2017). Big Data analytics and firm performance: effects of dynamic capabilities. Journal of Business Research, 70, 356-365. http://dx.doi.org/10.1016/j.jbusres.2016.08.009.

Wang, G., Gunasekaran, A., Ngai, E. W. T., \& Papadopoulos, T. (2016). Big Data analytics in logistics and supply chain management: certain invetigations for research and applications. International Journal of Production Economics, 176, 98-110. http://dx.doi.org/10.1016/j.jpe.2016.03.014. 